\title{
FEDERAL INCOME TAX: FURTHER COMMENTS ON REORGANIZATIONS
}

HOMER HENDRICKS †

I.

Although the Supreme Court decided the case of Gregory v. Helvering ${ }^{1}$ in January, I935, not until recently has the problem of its application to cases involving different sets of facts begun to clear. The lines of possible argument, at least, have become more distinct as a result of two recent decisions of the circuit courts of appeals; moreover, certain typical fact situations, which will be discussed later, have developed to the point of being litigated. It seems, therefore, that this is an appropriate time for further consideration of an already much discussed case, ${ }^{2}$ and for suggestions relating to the necessity or desirability of legislation on the part of Congress. In this latter connection, it seems possible that, as a result of expert studies now being made by the Treasury and by the staff of the Joint Committee on Internal Revenue Taxation, a general revision of the revenue laws will be made at the 1939 regular session of Congress.

So well known is the Gregory case that only such reference will be made to it as is necessary to state the facts involved and the holding of the Supreme Court. The case involved transactions which Mrs. Gregory meticulously planned, for the purpose of effecting a sale of property with the least possible amount of tax. She owned all the shares of the United Mortgage Corporation, among whose assets were some shares of another corporation, the Monitor Securities Corporation. It became possible to sell the Monitor shares at a large profit; but if this was done directly, United would have been compelled to pay a tax on the gain, and Mrs. Gregory, if she wished to receive the proceeds, would have been liable for surtax on a dividend. In order to reduce these taxes as much as possible, the following plan was carried out: Mrs. Gregory incorporated in the State of Delaware a new corporation, the Averill Company, to which United transferred the Monitor shares owned by it under an agreement by which Averill issued all of its shares to Mrs. Gregory. Having received the Averill shares, Mrs. Gregory wound up the Averill corporation three days later, receiving the Monitor

†LL.B., I92I, University of Texas; author, with Miller and Everett, of ReoRganizations aNd OtHER Exchanges IN FEDERAL INCOME TAXATION (I93I), and of numerous articles on the subject of federal taxation. Member of the District of Columbia Bar.

I. 293 U. S. 465 (I935).

2. See Miller, Corporate Reorganizations: The Present Situation (1934) I2 TAx MAG. 459, 46I; Griswold, Book Review (1935) 48 HARv. L. Rev. I032; (1934) 34 CoL. L. Rev. 965 [discussing Helvering v. Gregory, 69 F. (2d) 809 (C. C. A. 2d, I934)]; (I935) 48 HARv. I. REv. 852. For citations to subsequent decisions commenting on the Gregory case, see PAuL and Mertens, Federal Income Taxation (Supp. I937) § I7.48, n. 8d. 
shares as a liquidating dividend. These she sold immediately. It was not disputed that all of the transactions were parts of a plan to reduce taxes in connection with an intended sale. The Averill Company conducted no business nor was it intended to conduct any. Its sole purpose was to act as a conduit for the Monitor shares to Mrs. Gregory.

Mrs. Gregory contended that the transfer of the Monitor shares was a "reorganization" 3 and that there was no recognizable gain to her ${ }^{4}$ in the receipt of the new Averill shares; that when the Averill Corporation was liquidated, she realized gain (taxable as a "capital gain" at the flat rate of I2 $1 / 2$ per cent) ${ }^{5}$ only in the amount of the difference between the fair market value of the Monitor shares and her allocated basis for the Averill shares. ${ }^{6}$ Under that theory no additional gain would have been realized on the sale of the Monitor shares, inasmuch as Mrs. Gregory took them at a basis of their fair market value which was the same as the sale price. The Commissioner of Internal Revenue, however, was of opinion that the reorganization attempted was without substance and must be disregarded; and Mrs. Gregory was held liable for a tax as though the United Corporation had paid her a dividend consisting of the amount realized from the sale of the Monitor shares. The Commissioner's view was rejected by the Board of Tax Appeals, which sustained Mrs. Gregory.7 The Second Circuit Court of Appeals, however, upheld the Commissioner and reversed the Board on the ground that there was no "reorganization" within the intendment of the statute. ${ }^{8}$ This decision was affirmed by the Supreme Court in an opinion written by Mr. Justice Sutherland. ${ }^{9}$ The following seems to be a fair summary of the Court's holding and its reasons therefor:

I. The transfer was not made in pursuance of a plan of reorganization of "corporate business". The transfer of assets had "no relation to the business" of either the transferor (United Mortgage Corporation) or the

3. Under $\S$ II2 (i) (I) (B) of the Ig28 Act, 45 STAT. 8I8, which defined "reorganization" to include, among other things, "a transfer by a corporation of all or a part of its assets to another corporation if immediately after the transfer the transferor or its stockholders or both are in control of the corporation to which the assets are transferred." The corresponding provision of the 1936 Act is $\S \mathrm{II2}(\mathrm{g})(\mathrm{I})(\mathrm{C}), 49$ STAt. I68I, 26 U. S. C. A. §II2 (g) (I) (C) (Supp. I937).

Ed. Note: The full citation to the various Revenue Acts will be given the first time each appears. Thereafter reference will be made only to the sections of the various Acts.

4. Under $\S$ II $(\mathrm{g})$ of the I928 Act, which provided that no gain should be recognized to shareholders in respect of the distribution (without the surrender by the shareholders of stock or securities in the corporation making the distribution) of stock or securities in a corporation a party to the reorganization. This provision was dropped in the I934 Act and therefore does not appear in the I936 Act.

5. See $\S$ Ior of the Ig28 Act. The tax so computed was less in the case in question than the surtax would have been on a dividend.

6. See $\S I I 3$ (a) (9) of the 1928 Act, and U. S. Treas. Reg. 74, Art. 600.

7. 27 B. T. A. 223 (1932).

8. 69 F. (2d) 809 (C. C. A. 2 d, 1934).

9. 293 U. S. 465 (I935). 
transferee (Averill Company); it was "simply an operation having no business or corporate purpose". 10

2. The plan was "not to reorganize a business or any part of a business, but to transfer a parcel of shares to the petitioner" (Mrs. Gregory). The Averill Company "was brought into existence for no other purpose; it performed ... no other function. When that limited function had been exercised, it immediately was put to death." 11

The transfer had no relation to the business of the United Mortgage Company because from the standpoint of that company it was not material whether the assets were distributed to Mrs. Gregory or transferred to the new corporation. In other words, as far as United Mortgage was concerned, there was no reason why the assets should be transferred to the new company.

The transfer had no relation to the business of the Averill Company because that company never acquired the assets for itself; it was never intended that Averill should retain them and use them in the conduct of its business. On the contrary, the Averill Company was brought into existence solely for the purpose of transferring the assets to Mrs. Gregory and as soon as it had performed that function, it was put to death.

\section{II}

There are a number of typical fact situations on which it has been suggested, the decision in the Gregory case may have some bearing. These will be analyzed and, where possible, the income tax results which seem sound will be indicated. It should be borne in mind, however, that the results must remain uncertain until the views of the courts have been stated in more cases than have as yet been decided.

\section{Distribution of Dividend Followed by Transfer of Remaining Assets}

The least complicated of these several fact situations is the following: a corporation distributes a dividend of part of its assets to its shareholders, and thereafter transfers the remaining assets to another corporation in exchange for stock constituting less than a "controlling" 12 interest. A problem then arises whether or not "substantially all" the properties have been acquired by the other corporation so as to constitute one of the types of transactions which the Act defines as "reorganization". ${ }^{13}$ Does the fact

Io. $I d$. at 469 .

II. Ibid.

I2. See § II2 (h) of the I936 Act, which defines "control" as meaning "the ownership of stock possessing at least 80 per centum of the total combined voting power of all classes of stock entitled to vote and at least 80 per centum of the total number of shares of all other classes of stock of the corporation." Corresponding provisions of earlier acts, although not identical, were similar.

I3. § II2 (g) (I) (B) of the I936 Act provides: "The term 'reorganization' means ... (B) the acquisition by one corporation in exchange solely for all or a part of its voting stock - - of substantially all the properties of another corporation." Beginning with the Igar Act, $\$ 202$ (c) (2), 42 STAT. 230, all the revenue acts have provided that the acquisition, in a specified manner, by one corporation of substantially all the properties of another corporation constitutes "reorganization". 
that part of the assets of the corporation are distributed to the stockholders prevent the application of the reorganization provision? Putting it another way, in determining whether "substantially all" the properties are the subject of the reorganization transfer, is it sufficient that the corporation conveys all the properties which it owns at the moment of the transfer, or will inquiry be made into any antecedent distributions or transfers which the corporation may have made?

The Bureau practice until recently was as stated in G. C. M. I $345^{14}$ issued in I927. It was there held that a corporation might distribute a dividend of part of its assets to its stockholders prior to the transfer of all of its other assets in reorganization. ${ }^{15}$ The date of the issuance of this ruling is important, for it undoubtedly represented the views of the men in the Treasury Department who had been active in drafting the reorganization provisions which were incorporated in the Revenue Acts of I92I and I924. ${ }^{16}$ The administrative practice, as reflected in this ruling, was consistently followed by the Bureau of Internal Revenue for many years; and during this period Congress reënacted the statutory provisions without changes affecting the point in question. ${ }^{17}$

Considering the matter originally and apart from the effect to be given to Bureau practice, it would seem that Congress intended the transfer to be classed as a reorganization. The phrasing as well as the history of the statute indicates an intention that the tax results be the same in (I) reorganizations involving the acquisition by one corporation of "substantially all" the properties of another corporation and (2) reorganizations by way of "merger or consolidation". ${ }^{18}$ In the latter case, assets not apt to the

I4. VI-I CuMr. BuLI. I5 (I927). See infra notes 25, 48 and 49.

I5. The facts were that the $M$ Company, after a dividend distribution to its stockholders, transferred its remaining assets to the $S$ Company for stock in that company, which it distributed to its stockholders. "Since the actual transfer of the properties to the $S$ Company," said the General Counsel, "took place after the distribution by the $M$ Company of. . cash . . . and stock in the $Q$ Company, it constituted a transfer of substantially all the assets of one corporation to another, and, therefore constituted a reorganization." Compare I. T. 1850, II-2 CuMr. Bull. 8 (I923).

I6. The first provision for the type of reorganization involving the acquisition by one corporation of substantially all the properties of another corporation appeared in the Ig2I Act, $\$ 202$ (c) (2). In the I924 Act, $\$ 203,43$ STAT. 257, the reorganization provisions were revised and extended to types of transactions not theretofore covered.

I7. It may well be argued that the administrative practice has become a part of the reënacted statutes. United States v. Cerecedo Hermanos y Compañia, 209 U. S. 337, 339 (Ig08). But as to the limited effect to be given to Bureau rulings in this connection, see Helvering $\mathrm{v}$. New York Trust Co., 292 U. S. 455, 468 (I934).

I8. Beginning with the I92I Act, $\$ 202$ (c) (2), and continuing through the I932 Act, $\S$ II2 (i) (I), 47 STAT. 196, the provision relating to "substantially all" was a part of the same clause of the definition of reorganization which included mergers and consolidations. Thus the I932 Act, § II2 (i) (I), provided: "The term 'reorganization' means (A) a merger or consolidation (including the acquisition by one corporation of at least a majority of the voting stock and at least a majority of the total number of shares of all other classes of stock of another corporation, or substantially all the properties of another corporation). . . ." In the I934 and I936 Acts, $\$$ II2 (g) (I), there are changes in the language, but the changes have no effect on the basic concept that certain transactions not involving 
merger or consolidation are frequently distributed as a dividend or transferred to a separate corporation prior to the statutory ${ }^{19}$ merger or consolidation. Such transfers have quite often been made prior to the merger or consolidation of national banks. ${ }^{20}$ As is generally known, it is the practice of the Comptroller of the Currency to require that a bank being merged or consolidated into another banking corporation shall first divest itself of the ownership of undesirable assets. Obviously, in such a case, there is a statutory "merger" within the meaning of the tax law. It is believed that the courts should likewise hold that taxable gain does not result in other cases involving reorganizations of the type being considered here. No reason appears why Congress would have desired to make one rule applicable to statutory mergers and consolidations, and then outlaw similar transactions otherwise falling within what was intended to be an expanded ${ }^{21}$ meaning of "merger and consolidation".

The rule, suggested by the author as the correct one, not only works consistently with respect to statutory mergers and consolidations and the expanded mearings of those terms, but also results in certainty and definiteness. ${ }^{22}$ In determining whether "substantially all" the properties of one corporation have been acquired by another, if one follows the view of G. C. M. I 345 and looks at the date of the actual transfer of ownership of the properties in question, there is certainty. If any prior date is taken as the determining one, the question inevitably arises as to how far back into the history of the corporation and its properties it is necessary to go. The difficulties of administrative application of any such rule are obvious. ${ }^{23}$

\section{Transfer of Part of Assets to Controlled Corporation, Followed by Trans- fer of Remaining Assets to Outside Company}

A second typical fact situation is illustrated by Helvering v. Minnesota Tea Company, ${ }^{24}$ in which, however, the Supreme Court did not pass upon

strict merger or consolidation are permitted for the reason that they are akin to strict merger or consolidation and should therefore receive similar treatment. Cf. Helvering v. Minnesota Tea Co., 296 U. S. 378 (I935).

19. The term, "statutory merger or consolidation", as used here and at other places in the text of the article, relates to a transaction carried out in accordance with corporation laws (as distinguished from income tax statutes) of the states or of the United States. Compare U. S. Treas. Reg. 94, Art. I12 (g) -2 .

20. See, e. g., Walter Hopkins, 27 B. T. A. I33I, I333-I334 (1933) ; National Bank of the Republic of Chicago, 3I B. T. A. 680, 68I (1934); I. T. I850, II-2 Cun. Bull. 8 (1923).

21. See Pinellas Ice \& Cold Storage Co. v. Commissioner, 287 U. S. 462, 470 (I933).

22. See infra note 86 .

23. See also the dictum in the majority opinion in Helvering v. Elkhorn Coal Co., Prentice-Hall I937 Fed. Tax Serv. \1602, 374 C. C. H. I937 Fed. Tax Serv. I950I (C. C. A. 4th, I937), to the effect that a dividend followed by a transfer of the remaining assets to another corporation would classify as a reorganization because "the business enterprise would have definitely divested itself of the property distributed."

24. 296 U. S. 378 (I935). 
the question here to be considered. The facts were that on July I4, I928, the Tea company transferred part of its assets to a new corporation, called the Peterson Investment Company, in return for all the shares of the latter. These shares were distributed by the Tea company to its stockholders. The Tea company, on August 23, I928, transferred its remaining assets to another corporation, the Grand Union Company, in exchange for voting trust certificates, representing Grand Union shares (less than a "controlling" interest), plus a sum of cash. In accordance with the settled Bureau practice, the Commissioner of Internal Revenue ruled in the notice of deficiency that the transfer to Peterson constituted a non-taxable reorganization, and also that the transaction with the Grand Union Company was a reorganization which was non-taxable to the Tea company except to the extent that certain liabilities of the Tea company were assumed and paid by its stockholders. ${ }^{25}$

Not until the case reached the Supreme Court did the Government argue that the effect of the earlier transfer to Peterson was to prevent the acquisition by Grand Union of "substantially all" the properties of the Tea company. ${ }^{26}$ The Supreme Court, therefore, declined to consider the argument on the ground that it had been raisea too late.

Assuming that the question is properly raised in some other case, it would seem that both transactions should be held reorganizations. ${ }^{27}$ As has been. stated, that had been the established practice of the Bureau of Internal Revenue for many years. If the practice is considered as having been confirmed by the issuance of G. C. M. I345 in I927, it certainly was in effect as late as January 26, I93 I. $^{28}$ It is believed that it continued in effect until shortly after Judge Woodrough delivered his dissenting opinion in the Tea case on March 25, I935. There were at least no publicly issued rulings to the contrary. Thus, certainly for four years, and probably for

25. The Commissioner's notice of deficiency, dated Jan. 26, I93I, read: "With reference to the transfer of a portion of its assets to the Peterson Investment Company, since the Minnesota Tea Company or its stockholders or both were in complete control of the transferee immediately after the transfer, said transaction clearly constituted a reorganization under $\$$ II2 (i) (I) (B) of the I928 Act. . . . No taxable gain resulted. . . With reference to the transfer of the remaining assets to the Grand Union Company . . . it is to be noted that said assets constituted all the properties then owned by the Minnesota Tea Company. Said transfer, therefore, falls within the definition of a reorganization as set out in $\$ I I 2$ (i) (I) (A) of the Ig2S Act in that it was the acquisition by one corporation of all the properties of another corporation." See supra note I4, and infra notes 48 and 49.

26. The question was first raised in the dissenting opinion of Judge Woodrough in the Circuit Court of Appeals. See Minnesota Tea Co. v. Commissioner, 76 F. (2d) 797, 803 (C. C. A. 8th, I935).

27. Of course, under the existing law, in the second transaction the transferor would have to receive "voting stock" of the transferee and no other type of consideration. See $\S$ II2 (g) (I) (B) of the I936 Act. The discussion in the text of the article relates to the question whether, in the second transaction, substantially all of the properties of the transferor would be transferred.

28. This is the date of the Commissioner's notice of deficiency in the Minnesota Tea case, in which notice G. C. M. I345, VI-I CuM. BULL. I5 (I927), was cited with approval. See also infra notes 48 and 49 . 
eight years, the practice continued. In the meantime, Congress reënacted the relevant statutory provisions, without changes affecting this point, not only in the Revenue Act of r928, but also, if the longer period is correct, in the Revenue Acts of 1932 and $1934 .^{29}$ Moreover, as has been pointed out in the discussion of the situation where a dividend is distributed in advance of the transfer of the remaining assets to another corporation, the analogy to what could be done by the process of statutory merger or consolidation seems to confirm the view that the intentions of Congress were actually put into effect by the Bureau practice.

The decided case which most nearly resembles the fact situation in the Tea case is Helvering v. Elkhorn Coal Company. ${ }^{30}$ The Elkhorn Coal and Coke Company, on December 18 , I925, transferred part of its assets to a new corporation which it had organized, in exchange for the stock of the latter. The newly acquired shares were then distributed to the stockholders of the Coal company. Thereafter, on December $3 \mathrm{I}$, the old corporation transferred its remaining assets to the Mill Creek Coal and Coke Company, an existing corporation, in exchange for shares in Mill Creek representing less than a "controlling" interest. The stockholders of the old company then surrendered their shares in that company in exchange for additional stock in the new company, whereupon the new company caused the old company to be dissolved. Upon the dissolution, the new company received the shares of stock which the old company had obtained in Mill Creek. No business was done by the old company after the transfer of assets to Mill Creek; nor did it appear that there was any reason for the new company's organization except to provide a transferee to take over and hold the assets which were not to be transferred to Mill Creek, so that the transfer to that company when made would be a transfer of all the assets of the old company.

The court held that there was no reorganization within the meaning of Section 203 (h) (x) (A) of the Revenue Act of I926, covering the acquisition by one corporation of "substantially all the properties" of another corporation, and that the transfer by the old company of all the properties it owned on December 3I, I925, to the Mill Creek company was taxable. The court indicated that there was a mere shifting of charters since the new company was in reality the old one with a new corporate dress, there having been nothing more than minor changes in the legal papers under which it enjoyed corporate existence. It is arguable that the result is sound under

29. See supra note I7.

30. Prentice-Hall r937 Fed. Tax Serv. $\int 1602,374$ C. C. H. I937 Fed. Tax Serv. I 9501 (C. C. A. 4th, 1937) (dissenting opinion by Watkins, D. J.), reversing, 34 B. T. A. 845 (1936). See also A. W. Mellon, 36 B. T. A., Dec. 7, I937, in which, however, the Union Construction Co., which took assets of McClintic-Marshall not conveyed to Bethlehem Steel, was held to be ephemeral and in which there was also a question whether Bethlehem Steel was a "party" to a reorganization. 
the facts of the Elkhorn case. Certainly, where a corporation transfers less than substantially all its properties to another corporation in exchange for less than a controlling stock interest in the latter, the transaction does not constitute a reorganization as defined by the statute. In the Elkhorn case, therefore, it may be argued that there was never any real change in the corporation. $^{31}$ It should be observed, however, that the final status could have been reached, without tax, by means of a statutory merger. For example, after the organization of the new company and the transfer of assets to it, the old company could have been merged into the Mill Creek company; the shareholders of the old company would have received shares of Mill Creek, and these shares might then have been turned over by the shareholders to the new company in exchange for additional shares of the new company. There is, therefore, doubt as to the soundness of the conclusion which the court reached. In any event, the case is different on its facts from one where the old corporation declares a dividend and then transfers its remaining assets to another corporation or from one where the final result is that the stockholders own shares in two corporations instead of only one.

\section{Transfer of Part of Assets to Controlled Corporation, Followed by Transfer of Its Stock to an Outside Company}

The third of the typical fact situations is illustrated by Ballwood Company v. Commissioner ${ }^{32}$ and Independent Oil Company. ${ }^{33}$ Since the facts in the two cited cases are similar, only those in the former will be stated in detail. The Ballwood Company, in accordance with an agreement made with Midwest Pipe \& Supply Company, conveyed its pipe fabricating assets, representing approximately 29 per cent of its total assets to the newly organized Ballwood Pipe Fabricating Corporation. Ballwood Company received all of the new corporation's capital stock and conveyed the same to Midwest in exchange for approximately I8 per cent of Midwest capital stock. The new corporation continued in existence as a holding company for the assets transferred to it by the Ballwood Company. The court held that there was a non-taxable reorganization within the meaning of Section II2 (i) (I) (A) of the Revenue Act of 1928 because Midwest acquired the stock of the new company. The court indicated that the statute should be literally construed. ${ }^{34}$

3r. One of the types of transactions which the revenue acts define as reorganization is "a mere change in identity, form, or place of organization, however effected." See $\$ 203$ (h) (I) (D) of the 1926 Act, 44 STAT. I2. The provision appears in the I936 Act as $\S$ II2 (g) (I) (E). It may be argued that such is what took place in the Elkhorn Coal case, and that the transfer to Mill Creek was taxable the same as if the original enterprise had made it.

32. 84 F. (2d) 733 (C. C. A. 3d, I936).

33. 35 B. T. A. 32 (1936), now on appeal by Commissioner to C. C. A. 3d.

34 "Giving the words of the statute their plain and unambiguous meaning, we must reach the conclusion that what took place in the instant case amounted to a statutory reorganization in which there was no gain or loss. . ." 84 F. (2d) 733, 735 (C. C. A. 3d, I936). 
The facts in Independent Oil Company ${ }^{35}$ were slightly different from those in the Ballwood case in that, following organization of the new corporation which acquired part of the assets of the petitioner, the petitioner exchanged only 75 per cent of the shares of the new corporation ${ }^{36}$ with an outside corporation (Vacuum Oil Company) for shares of the latter. ${ }^{37}$ The Board considered the case from the standpoint of whether it comprised only one transaction or two different transactions, and held that, under either view, there was a non-taxable reorganization. The opinion analyzes the results which would follow from the adoption of either view, and it is therefore of considerable value in outlining the issues which logically arise in a case of this sort.

"Viewing the transactions . . .", said the Board, "as an accomplished result . . . and considering the result first from the standpoint of the petitioner . . . at the conclusion of the transactions, in place of direct ownership it had a 25 per cent interest through stock ownership in the transferee plus the interest represented by the income certificates, and also a further substantial interest through its stock interest in Vacuum, which owned the other 75 per cent of the transferee's stock." It thus concluded:

"While the petitioner's relationship to the assets was substantially changed, nevertheless it acquired and held a definite and substantial - interest in the transferee." 38

The foregoing is not convincing, in the opinion of the writer; for if the transactions are viewed "as an accomplished result", it would seem pertinent to inquire what the petitioner had in the beginning and obtained in the end. When so viewed, it is apparent that the petitioner entered the transactions with the assets which were the subject of the deal and emerged from them with less than a controlling interest in either the new company or in Vacuum. Thus, there would be no "reorganization" as defined in the statute. The following excerpt taken from the opinion of the Board, however, seems to show the futility of arguing that there was only one transaction when in fact there were two:

"Still viewing the transactions as a whole, but from the standpoint of Vacuum's participation, we find that what occurred was that Vacuum acquired 75 per cent of all the stock of the new corporation. . . .

35. 35 B. T. A. 32 (I936).

36. In the Ballwood case, as has been stated, the Ballwood Company transferred all of the shares of the newly organized company to the Midwest Company in exchange for Midwest shares.

37. The petitioner thus retained 25 per cent of the shares of the new company. It also retained certain income certificates which the new company issued, but it was agreed the certificates were without value.

38. $I d$ at 37 . 
This acquisition contains all the elements of the definition of reorganization in Section II2(i) ( 1 ) (A) of the Revenue Act of I928." 39

In other words, if the new corporation was a real one (and it was since it continued to operate and was not merely organized as a sham to conceal the real motive of the transaction as in the Gregory case), the facts are susceptible of only one construction; namely, that the Vacuum Company acquired shares of the new company's stock. Since Vacuum acquired these shares, and not the assets which the petitioner corporation possessed at the outset, it follows that a "reorganization" took place, as is always the case where the requisite amount of the shares of one corporation is acquired by another. Under the two-step theory of the case, the steps were (I) the transfer of assets by the petitioner to the new corporation in return for the stock and income certificates of the new corporation, and (2) the exchange of 75 per cent of the stock of the new corporation with Vacuum for shares of Vacuum.

The petitioner, of course, relied on the statutory provisions covering transfers of properties to "controlled" corporations 40 to support its contention that no tax was due on the first of the transactions; as to the second, it was argued that there was a reorganization because the Vacuum company acquired stock of the new corporation. The Commissioner contended that, in any event, tax was due on the first transaction ${ }^{41}$ because the petitioner did not remain in control of the new corporation; and that under cases ${ }^{42}$ viewing a series of transactions as only parts of the whole, there

39. $I d$. at 38 .

40. See $\$ I 12$ (b) (5) of the I928 Act (same as $\$ I I 2$ (b) (5) of the I936 Act) which provides in part: "No gain or loss shall be recognized if property is transferred to a corporation by one or more persons solely in exchange for stock or securities in such corporation, and immediately after the exchange such person or persons are in control of the corporation. . . ."

See also $\S$ II2 (i) (I) (B) of the Ig28 Act (same as $\$$ II2 (g) (I) (C) of the r936 Act) which defines the term "reorganization" to include "a transfer by a corporation of all or a part of its assets to another corporation if immediately after the transfer the transferor or its stockholders or both are in control of the corporation to which the assets are transferred."

As to meaning of "control" see supra note 12.

41. Compare infra note 49.

42. The brief for the Commissioner relied on the following cases: West Texas Refining \& Development Co. v. Commissioner, 68 F. (2d) 77 (C. C. A. Ioth, r933) : Here Corporation $A$ transferred part of its assets to new Corporation $B$ in exchange for one-half of $B^{\prime}$ s stock and a sum of cash; the cash was raised by $B$ from the sale of the remaining one-half of its stock to Corporation $C$. The court held that $A$ was taxable on the sale of the assets to $B$ since it received only one-half of $B$ 's stock and therefore did not control $B$. It seems clear that the organization of $B$ as planned was not completed until it had sold the remaining one-half of its stock to $C$ and thus the case is distinguishable from Independent Oil Company, discussed in the text; Hazeltine Corp., 32 B. T. A. IIo (I935): In this case also the organization of the new company was not completed until a large block of its stock had been sold by it to outside interests for cash; Wilbur F. Burns, 30 B. T. A. I63 (1934) and Haliburton v. Commissioner, $78 \mathrm{~F}$. (2d) 265 (C. C. A. 9th, I935), the two other cases relied on by the Commissioner, are to similar effect. 
was no statutory control by the petitioner immediately after the exchange. To this the Board replied:

"But the assertion of this view is directly opposed to that of each step being a separate transaction. . . . If each step is separate, then the fact that each was pursuant to a plan is immaterial on this point." ${ }^{43}$

Of course, if the Board was correct in holding that the transactions viewed as a whole constituted a non-taxable reorganization, that should end the question with respect to the situation in the Independent Oil case. As has been indicated, that view seems unsound. It would be preferable to follow the two-transaction theory since the stock of the new company alone was the subject of the second transaction and was all that the outside corporation acquired. Therefore, the question to be decided is whether the taxpayer remains in control of the new corporation "immediately after the exchange". ${ }^{44}$ The word "immediately" was apparently inserted in the law for the purpose of making it clear that the provisions of the statute are satisfied when control exists as soon as the transfer of properties is made. Any other interpretation would give the word no significance, and so definite a word cannot be presumed to have no significance. Congress seems to have relied on the provisions of the law on the subject of "basis" 45 to protect the revenues. Thus, assuming a sale of the new stock or securities for cash, the same amount of gain or loss would be recognized as if the original property had been retained and a sale made of it. Furthermore, in the case of a subsequent exchange of the new stock or securities in a tax free transaction, the stock or securities received on the second exchange have in the hands of the taxpayer the same basis as the original properties; and on any later sale for cash, the full amount of gain or loss is recognizable. ${ }^{46}$

The administrative practice of the Bureau, at least until quite recently, has been to the effect that control at the moment when the transfer is made is sufficient. ${ }^{47}$ In this connection, it is important to note that the point was not raised in the Ballwood case, ${ }^{48}$ but only in the Independent Oil case, which

43. 35 B. T. A. 32, 37 (1936).

44. See supra note 40 .

45. See $\S \operatorname{Ir}_{3}$ (a) (6) of the 1936 Act and corresponding provisions of the prior acts. See also infra note 86 .

46. Ibid.

47. See G. C. M. 7285, IX-I Cum. Buls. I8I (I930). No published rulings to the contrary have ever been issued. See also Hazleton Corp., 36 B. T. A., Nov. 23, 1937.

48. The Commissioner's notice of deficiency in the Ballwood case, dated Mar. 23, I932, stated the Commissioner's position as follows:

". . . it is found that on April I, I929, when you transferred your pipe fabricating assets . . . to the Ballwood Pipe Fabricating Corporation, the new company was formed by you on the above date, for all of its capital stock, consisting of 5,000 no par shares; thereafter you were in control of the transferee corporation and there was a reorganization as defined by $\S$ II2 (i) (I) (B) of the Revenue Act of 1928 , and under the provisions of $\S$ II2 (b) (4) of the same Act, no gain or loss is recognized." 
was briefed and argued ${ }^{49}$ after the former had been submitted to the circuit court of appeals. ${ }^{50}$

As in the Independent Oil case, therefore, if the transferor actually makes a transfer of properties to the new corporation and actually owns the stock of the new company immediately after the transfer, and the company continues to own the properties, ${ }^{51}$ it would seem that no tax is due on the initial transaction even though the transferor thereafter disposes of all or any part of the new stock.52

\section{Transfer of Part of Assets to Controlled Corporation, Followed by Trans- fer of Its Assets to an Outside Company}

A fourth typical variation of the fact situation may be illustrated as follows: Corporation $A$ transfers part of its assets to newly organized Corporation $B$ in exchange for all of the stock of $B$. Thereupon $B$ transfers the properties to an outside company in exchange for stock of the outside company representing less than a "controlling" interest.

The arguments against the recognition of gain are: ( $I$ ) in the first transaction Corporation $A$ transferred property to a corporation, in exchange for stock and immediately after the exchange it was in control of the transferee; ${ }^{53}(2)$ the second transaction is a "reorganization" because the outside company acquired "substantially all" the properties of Corporation $B .{ }^{54}$

"It is also found that on the same date, April I, I929, you exchanged the 5,000 shares of the Ballwood Pipe Fabricating Corporation stock for $x, 000$ shares of common stock and 3,500 shares of preferred stock of the Midwest Piping and Supply Co. ... Since you did not acquire a majority of the voting stock and a majority of all other classes of stock of the Midwest . . . and thereafter you had no authority or control over the Ballwood Pipe Fabricating Corporation, this transaction was not a reorganization within the meaning of $\S$ II2 of the Revenue Act of I928. ..."

49. The record of the Independent Oil case on file with the Board of Tax Appeals indicates that the point was not suggested until the case came up for hearing on Oct. 28, 1935, at which time the attorney for the Government referred to it in his opening statement. The Brief for Respondent, filed with the Board on Feb. I4, 1936, was the first document filed which raised the point.

The Commissioner's notice of deficiency, dated Aug. 5, I932, had stated the Commissioner's position in the case as follows: "It is noted that during the year under review you transferred certain of your assets to the Independent Oil Co., Inc. . . . for its capital stock of 35,000 shares. Subsequently, $75 \%$ of such stock or 26,250 shares were transferred to the Vacuum Oil Company. . . . This office holds that the profit resulting from the latter transaction was taxable. Since the assets transferred to the Independent Oil Co., Inc. . . . had a cost value of $\$ I, 223,225.35$, it follows that the cost of the stock acquired (35,000 shares) had the same value. Accordingly, when $75 \%$ of such stock was subsequently sold, the cost thereof was $75 \%$ of $\$ 1,223,225.35$ or $\$ 917,419.01$. . ."

50. On July I6, I935, the circuit court of appeals affirmed, per curian, a decision of the Board of Tax Appeals (30 B. T. A. 644 (I934)) for the Commissioner in the Ballwood case. Later, on rehearing, the prior decision affirming the Board was vacated and the decision of the Board was reversed. See 84 F. (2d) 733,736 (I936).

5I. As to the effect of a prompt disposition of the properties by the new company, see infra p. 6I5.

52. See Hazleton Corp., 36 B. T. A., Nov. 23, r937.

53. See $\S$ II2 (b) (5), also $\S$ Ir2 (g) (I) (C) and II2 (b) (4) of the I936 Act.

54. See $\$ 112(\mathrm{~g})(\mathrm{I})(\mathrm{B})$ and $112(\mathrm{~b})(4)$ of the 1936 Act. 
The arguments in favor of the recognition of gain are the same as have been stated in the discussions relating to the fact situations in the Minnesota Tea and the Ballwood and the Independent Oil cases. In addition it may be argued that, when the two transactions have been completed, there is a lack of "continuing interest" on the part of Corporation $A$ and that, accordingly, $A$ is taxable on any gain which has been realized. Since this argument has not been discussed in connection with the other situations, some attention will be given to it here.

The stațute does not in terms lay down any requirement of "continuing interest" as a condition to the application of the reorganization provisions. This requirement is the result of court decisions interpreting Section Ir2(i) (I) of the 1928 Act. 55 That section provided that the term "reorganization" meant, among other things:

"(A) a merger or consolidation (including the acquisition by one corporation of at least a majority of the voting stock and at least a majority of the total number of shares of all other classes of stock of another corporation, or substantially all the properties of another corporation)."”

It became necessary to construe the words within the parentheses, and to state the extent, if any, to which they were affected by the words "merger or consolidation" which preceded them. In Cortland Specialty Company v. Commissioner, ${ }^{56}$ where one corporation acquired substantially all the properties of another corporation in exchange for short term notes, the Second Circuit Court of Appeals held that there was no "reorganization." 57 In the course of its opinion the court referred to the "necessity of continuity of interests under modified corporate forms" 58 and to the fact that each transaction described in the definition of reorganization pre-supposed "a continuance of interest on the part of the transferor in the properties transferred." 59 Thus was announced for the first time the doctrine of continuing interest. Later, a case involving similar facts reached the Supreme Court; and in Pinellas Ice \& Cold Storage Company v. Commissioner ${ }^{60}$ the Court, holding that there was no reorganization, said:

"Certainly, we think that to be within the exemption the seller must acquire an interest in the affairs of the purchasing company more definite than that incident to ownership of its short term purchase money notes." 61 Act.

55. And corresponding provisions of prior Acts; e. g., $\$ 203$ (h) (I) (A) of the 1926

56. 60 F. (2d) 937 (C. C. A. 2d, I932), cert. denied, 288 U. S. 599 (I933).

57. The case arose under the 1926 Act and involved $\S 203$ (h) (I) (A), which contained the same language as $\$$ II2 (i) (I) (A) of the I928 Act.

58. $60 \mathrm{~F}$. (2d) 937,940 (1932).

59. Ibid.

60. 287 U. S. 462 (I933). The case involved $\S 203$ (h) (I) (A) of the r926 Act.

6r. Id. at 470 . (Italics supplied.) 


\section{And later in the Minnesota Tea case, the Supreme Court stated:}

"And we now add that this interest must be definite and material; it must represent a substantial part of the value of the thing transferred. This much is necessary in order that the result accomplished may genuinely partake of the nature of merger or consolidation." 62

Returning to the typical fact situation stated above, what is to be said on the question of "continuing interest"?

Obviously, if the second transfer is to be separated from the first in determining the tax results, the transferor in the second transaction has a sufficient continuing interest. For in that transaction, Corporation $B$, in exchange for its properties, receives a stock interest in the corporation which acquires the properties and which retains the properties when it receives them. ${ }^{33}$

As to the first transfer, that is, the transfer by Corporation $A$ of part of its assets to $B$, closer analysis is required because of the fact that $B$ does not keep the assets but instead transfers them to still another company. Thus, if there is a "continuing interest", it is by reason of the fact that $A$ owns the stock of $B$, which in turn owns stock in a third company which in turn owns the properties. ${ }^{64}$

Although it is uncertain what the courts will ultimately hold, it would seem that they should find that the requirements of the statute have been met. ${ }^{65}$ The provisions to be construed refer to control "immediately" after the transfer, and the doctrine of continuance of interest is at the most only a gloss on the statute. It should, therefore, perhaps not be extended beyond the limits of the cases already decided. Moreover, the established administrative practice of the Bureau of Internal Revenue has been in accordance with the taxpayer's position on the question. All these factors point to the conclusion that the interest which continues, in the case stated, complies with the requirements of the law. ${ }^{66}$

62. 296 U. S. 378,385 (I935).

63. It is assumed that $B$ retains the stock in the acquiring company which $B$ receives.

64. Although the court in the Cortland Specialty case, 60 F. (2d) 937,940 (C. C. A. 2d, I932), referred to "a continuance of interest on the part of the transferor in the properties transferred" (italics supplied), it does not appear that a situation of the kind considered in the text of the article was in mind.

65. But see the following language in the majority opinion in Helvering $v$. Elkhorn Coal Co.: "If the property which was to be transferred to Mill Creek had been transferred to a new company created for the purpose and had been by that company transferred to Mill Creek no one would contend that there was a distinction" [and that no tax was due]. Prentice-Hall r937 Fed. Tax Serv. II 1602, 374 C. C. H. 1937 Fed. Tax Serv. I 9501 (C. C. A. 4th, 1937).

66 . It can also be argued, in support of this view, that continuance of interest in the "investment", as distinguished from particular "properties" is sufficient. Obviously, Congress did not intend that the properties should never be disposed of. The disposition, when as and if made, under this view, is to be given whatever tax effects are prescribed by the applicable provisions of the law. Thus, if the initial transferee corporation sells the properties for cash, taxable gain or loss is realized by it; but if a tax free reorganization takes place, the tax reckoning is postponed until the stock or security consideration received is disposed of in a transaction which is taxable. See, however, the majority opinion by Mr. Justice Brandeis in 


\section{Relationship Between Clauses of "Reorganization" Definition}

One further problem, arising under each of the four typical fact situations, must be considered. It relates to the limiting effect, if any, which the various clauses in the definition of "reorganization" may have upon each other. Thus, one of the clauses relates to the acquisition by one corporation of "substantially all" the properties of another corporation; ${ }^{67}$ whereas another clause relates to the transfer by a corporation of "all or a part of its assets" to another corporation if immediately after the transfer the transferor or its stockholders or both are in control of the corporation to which the assets are transferred. ${ }^{68}$ It may be argued, therefore, that Congress intended that in no case, whether by means of only one transaction or more than one, should a corporation be permitted to make a tax free transfer of anything less than "substantially all" of its properties unless the transferor or its stockholders are in control of the corporation which acquires the properties.

Some reference to the relationship between these two clauses appears in the opinion of the Supreme Court in the Minnesota Tea case. There the Government argued that the clause relating to reorganizations involving "substantially all" the properties of a corporation should be restricted in order to prevent overlapping and negation of the condition, relating to control, in the other clause of the definition to which reference has been made. ${ }^{69}$ The Supreme Court rejected the argument and said:

"We find nothing in the history or words employed which indicates an intention to modify the evident meaning of (A) by what appears in (B). Both can have effect, and if one does somewhat overlap the other the taxpayer should not be denied, for that reason, what one paragraph clearly grants him." 70

The clause covering the acquisition by one corporation of substantially all the properties of another corporation first appeared in the Revenue Act of

Helvering v. Bashford, 58 Sup. Ct. 307, 309 (I938) (Justices McReynolds, Sutherland and Butler dissenting), in which he said: "Any direct ownership by Atlas of Peerless, Black Diamond, and Union was transitory and without real substance; it was part of a plan which contemplated the immediate transfer of the stock or the assets or both of the three reorganized companies to the new Atlas subsidiary. . . The continuity of interest required by the rule is lacking." And see Groman v. Commissioner, 302 U. S. 82, 89 (1937), in which the Court said:". . . where, pursuant to a plan, the interest of the stockholders of a corporation continues to be definitely represented in substantial measure in a new or different one, then to the extent, but only to the extent, of that continuity of interest, the exchange is to be treated as one not giving rise to present gain or loss."

67. See $\S I I 2(g)(I)(B)$ of the I936 Act, and corresponding provisions of prior Acts.

68. See $\S \mathrm{II} 2$ (g) (I) (C) of the I936 Act, and corresponding provisions of prior Acts.

69. The Minnesota Tea case had to do with $\S$ II2 (i) (I) of the 1928 Act.

70. 296 U. S. 378,384 (I935). Clauses (A) and (B) referred to by the Court are of $\S$ II2 (i) (I) of the I928 Act; the respective corresponding clauses in the r936 Act are (B) and (C) of $\S \mathrm{II2}(\mathrm{g})(\mathrm{I})$. 
I921. ${ }^{71}$ The clause relating to transfers to controlled corporations first appeared in the Revenue Act of $1924 .^{72}$ The legislative history of the latter act conclusively shows that there was no intent on the part of Congress to limit the provisions of the former, clause by what appeared in the latter clause. $^{73}$

\section{The Nature of the New Corporation}

In connection with the fact situations which have been discussed, as well as any other plan of reorganization under which a new corporation is organized, consideration should be given to the nature of the new corporation. Thus, if the new company has only an ephemeral existence as a corporation, as was true in the Gregory case, the proceeding is to be classified as a sham and, therefore, not a "reorganization" within the intendment of the Act. A number of cases, involving corporations which were ephemeral and in which it was properly held that no reorganization occurred, are cited in the footnote. ${ }^{74}$

In Electrical Securities Corporation v. Commissioner ${ }^{75}$ the new corporation which was relied upon by the taxpayers as one which engaged in a reorganization transaction was dissolved shortly after the transaction took place. Of course, the court held that a reorganization had not been accomplished. The opinion went further and discussed generally the problem as to what circumstances must exist if there is to be a real "corporation" within the meaning of the reorganization provisions. The views thus expressed, coming as they do from the circuit court of appeals which decided the Gregory case for the Government and which, in that case, outlined the theories later approved, with some modification, by the Supreme Court, are of great value. In the Electrical Securities case, the court said that in the reorganization provisions:

". . . it was presupposed that the enterprises were in fact businesses; financial, commercial, industrial and the like. The avoidance or suspension of taxes is not a business." 76

Thus, the significance of the Gregory case and all other situations where the corporation does nothing except act as a vehicle for the attempted

7I. $\$ 202(\mathrm{c})(2)$ of the I92I Act.

72. $\$ 203$ (h) (I) (B) of the I924 Act.

73. The history of the provisions is outlined with painstaking care in Minnesota Tea Co. v. Commissioner, 76 F. (2d) 797 (C. C. A. 8th, 1935). See also Helvering v. Minnesota Tea Co., 296 U. S. 378 (I935).

74. See Royal Marcher, 32 B. T. A. 76 (I935) (corporation not formally dissolved, but owned no assets) ; Handbird Holding Corp., 32 B. T. A. 238 (I935); Thomas N. Perkins, 33 B. T. A. 606 (1935); Robert R. McCormick, 33 B. T. A. I046 (1936); Helen Sperry Lea, 35 B. T. A. 243 (1937); Philip J. Cogan, 36 B. T. A. 639 (I937).

75. 92 F. (2d) 593 (C. C. A. 2d, 1937).

76. Id. at 595 . 
avoidance or stispension of taxes becomes apparent. In order for there to be a reorganization, the corporation in question must be in fact a business enterprise. And the concept of "business" includes financial, commercial, industrial and similar enterprises. A corporation which actually holds securities would be a financial enterprise; one which conducts commercial operations, or which conducts industrial operations, would be a commercial or industrial enterprise, as the case might be.

Even though created for the purpose of postponing the tax, if the corporation actually holds the properties transferred to it, it has reality and the transaction may be classified as reorganization. ${ }^{77}$ Thus, in referring to the facts of the Minnesota. Tea case, the opinion states that the taxpayer, to bring itself within an exemption, as a first step sold part of its assets to another company, and then concludes:

"The first buyer was however intended to hold the assets which it got, and apparently continued to hold, and use, them for its own corporate purposes; if so, it was a business corporation, and the purposes of the particular transaction did not matter." 78

The same thought was advanced in the opinion when the Ballwood case was analyzed; ${ }^{79}$ and as to the case directly under consideration, the court said :

"... the Diselin Corporation was not a business corporation if tax avoidance or suspension is not a business; it had no other reason to exist, and it did nothing but act as a momentary conduit for the United Gas Improvement shares." 80

A different approach is indicated by language which the Fourth Circuit Court of Appeals used in deciding Helvering v. Elkhorn Coal Company. The court said:

"A careful consideration of the evidentiary facts discloses no purpose which could have been served by the creation of the new company . . . except to strip the old company of all of its properties which were not to be transferred to the Mill Creek Company." 81

77. The views of the second circuit as set forth in the Electrical Securities case were somewhat foreshadowed by the following remarks of the same court in Chisholm v. Commissioner, 79 F. (2d) I4, I5 (r935), cert. denied, 296 U. S. 64I (I935): "In Gregory v. Helvering. . the incorporators adopted the usual form for creating business corporations; but their intent, or purpose, was merely to draught the papers, in fact not to create corporations as the court understood that word. . . . Had they really meant to conduct a business by means of the two reorganized companies, they would have escaped whatever other aim they might have had, whether to avoid taxes, or to regenerate the world."

78. 92 F. (2d) 593,595 (C. C. A. 2d, 1937).

79. Ibid.

8o. Ibid.

8I. Prentice-Hall I937 Fed. Tax Serv. đI602, 374 C. C. H. I937 Fed. Tax Serv. 1950 I (C. C. A. 4th, I937). 
The dissenting opinion by Judge Watkins is in accord with the interpretations advanced by the second circuit in the Electrical Securities case. He was of the opinion that there was a non-taxable reorganization, and said:

". . . in the instant case . . . the new corporation immediately entered into the active business of mining and has ever since discharged the mining functions for which it was chartered, and . . . the Mill Creek Company, in which other shares were acquired, was then fulfilling, and is still fulfilling, its corporate business of mining. . . . [there was] no sham or pretense about the whole matter." 82

Thus, in two opinions of the courts, the lines of the argument are drawn. ${ }^{83}$ In the view of the second circuit, if the new corporation, although created solely with a view to the avoidance or postponement of tax, actually holds the properties and conducts its business-financial, commercial, or industrial-it is a business corporation and not a sham and the purposes of the particular transaction do not matter. In the view of the majority opinion of the fourth circuit, the fact that the new corporation conducts business is not enough if the sole reason for its creation is to avoid or postpone tax. Stated in another way this means that there must be a non-tax purpose which is served by the creation of the company.

Of course, under either view if the corporation does not actually receive properties for its own account and has only an ephemeral existence, it cannot be a party to a reorganization for it would be an artifice or sham, and therefore, reality for income tax purposes is not to be accorded it. This follows, of course, from the Supreme Court's holding in the Gregory case.

Also it may be assumed that, under either view, if there is a non-tax reason for the creation of the corporation and it actually enters into the business for which it was chartered, it can be a party to a reorganization, even though one of the principal reasons, but not the sole reason, for the creation of the company is the avoidance or postponement of tax. This also seems to follow from the decision in the Gregory case about "the legal right of a taxpayer to decrease the amount of what otherwise would be his taxes, or altogether avoid them, by means which the law permits . . . ." 84

As to the cases where the sole reason for the creation of the corporation is to avoid or postpone the tax, but the corporation actually conducts in a permanent way the operations for which it is chartered, it is believed that the view of the second circuit is sound and that such a corporation should be treated as a "corporation" for the purpose of the reorganization provisions. It is believed, moreover, that this result was in the minds

82. Ibid.

83. There does not, however, appear to be any "conflict" such as would be a ground for certiorari to the Supreme Court, for the reason that in each case the court held there was no reorganization.

84. 293 U. S. 465,469 (1935). 
of the Treasury draftsmen when they prepared the reorganization provisions in the Revenue Bill of $1924{ }^{85}$ enacted as a part of the I924 Act and continued in the subsequent revenue acts. The administrative practice, already referred to, confirms this. The general purposes of Congress in the enactment of the reorganization provisions seem also to confirm this result; the provisions were regarded as self-executing; reliance was placed on disallowance of losses and on the so-called basis provisions for the protection of the revenues. ${ }^{86}$

\section{III}

Assuming that the existing law is as stated, should there be any changes made by way of legislation affecting future transactions? ${ }^{87}$

The mechanics of any such change would be simple enough. If Congress desires to exclude the so-called multiple step reorganizations from the operation of the reorganization provisions, this could be done by the enactment of a provision, in effect, as follows: if property received in any single exchange transaction, in which the full amount of gain is not completely recognized, is later disposed of (say, within twelve months of the original transaction), the full amount of gain (if any) ${ }^{88}$ shall be recognized on the second transaction unless prior thereto the taxpayer shall establish to the satisfaction of the Commissioner that such later disposition is not in pursuance of a plan having as one of its principal purposes the avoidance of federal income taxes. ${ }^{89}$

A different statutory provision would be necessary in respect to (I) the distribution of dividends or (2) the organization of a separate corpora-

85. H. R. 6715, 68th Cong., Ist Sess. (I924).

86. The committee reports which accompanied the Acts of Ig2r and Ig24 show that the general purposes were: (I) To remove impediments to ordinary business transactions, which otherwise would not be consummated on account of the provisions of the tax law heavily taxing gains which were realized only in the form of stock or securities, in "paper" profits so to speak. (2) To disallow losses which would have been deductible as a result of such transactions. (3) To provide for certainty in the rules governing the tax effects of such transactions, certainty being desirable from the standpoint of the taxing authorities as well as that of the taxpayer. (4) To rely on the "basis" provisions, substituting the cost basis of the property formerly owned as the cost basis on the property newly-acquired (with adjustments for gain or loss recognized on the transaction in question), as a means of safeguardnig the revenues and equitably preserving any "loss" position of the taxpayer. As to ( $I$ ) see: SEN. REP. No. 275, 67th Cong., Ist Sess. (Ig24) II, I2; H. R. REP. No. 350, 67th Cong., Ist Sess. (1924) Io; Sen. Rep. No. 398, 68th Cong., Ist Sess. (I924) I4, I5; H. R. REP. No. I79, 68th Cong., Ist Sess. (I924) I3. As to (2): SEN. REP. No. 275, loc. cit. supra; H. R. REP. No. 350, loc. cit. supra. As to (3): H. R. ReP. No. I79, loc. cit. supra; also the views of the Democratic Minority of the Committee, at 77 of the same report; SEN. REP. No. 398, supra, at I4. As to (4): H. R. REP. No. 350, loc. cit. supra; SEN. REP. No. 275, supra, at I2; H. R. REP. No. I79, supra, at I6-I7; SEN. REP. No. 398, supra, at I7-I8.

87. Of course, any such legislation should not be retroactive in the sense of affecting transactions which have already been consummated. All such transactions should stand or fall according to the law which was in force when they took place.

88. Since the deductibility of so-called capital losses is limited by other provisions of the existing law [see I936 Act, \$II7 (d)], no further provision would seem necessary in respect of losses.

89. Compare the provisions of the I936 Act, $\S$ II2 (i), with respect to transactions involving foreign corporations. 
tion to hold assets, prior to (3) the transfer by an existing corporation of its remaining assets to still another non-controlled corporation. ${ }^{90}$ But since both are procedures which may be followed in connection with statutory mergers and consolidations, ${ }^{91}$ they may well be permitted where the procedure is one of non-statutory merger or consolidation. Furthermore, since it is in the interest of the Government not to interpose handicaps on the consummation of bona fide business reorganizations, it would seem that no such new provision ought to be enacted.

It may even be contended that there is no occasion for the enactment of a provision affecting multiple step reorganizations. The "basis" provisions of the existing law, certainly, go a long way towards protecting the revenues. ${ }^{92}$ Moreover, the tax on inter-corporate dividends, ${ }^{93}$ whatever may be its merits in other connections, most certainly acts as a brake upon the creation of needless "tax" corporations, as do also the surtax on undistributed profits, ${ }^{94}$ the taxes on capital stock ${ }^{95}$ and excess profits ${ }^{96}$ and the surtax on personal holding companies. ${ }^{97}$

In any event, the fundamental principle of not taxing reorganizations and similar transactions should be continued in any revision of the revenue laws. At the present time when the freezing-up effects of severe methods of taxing capital gains are being felt in the revenues and when the burden of the tax on capital gains probably ought to be reduced, ${ }^{98}$ no substantial narrowing of the reorganization provisions should take place. It would also be a mistake to attempt any complete revision of these provisions. Having been in the acts in substantially the same form for almost fourteen years ${ }^{99}$ and having been amended from time to time as occasion required, the various concepts on which they are drawn have become understood and the meanings of the various phrases have been worked out in litigated

90. See sipra pp. $604,606$.

9I. See stipra pp. 605, 609.

92. Unlike the provisions of former laws, no so-called "step-ups" of basis are now permitted on properties in the hands of corporations which are transferees in tax-free reorganizations, not even in cases where the transferee is owned by almost entirely different interests from those owning the transferor. See 1936 Act, $\$$ II3 (a) (7).

93. Under 1936 Act, $\$ \S 13$ (a) (2) and 26 (b), fifteen per cent of the amount, which a corporation receives as dividends from domestic corporations, is subjected to the normal tax on corporations. No credit whatever is given to the recipient corporation in respect of such items, for the purpose of the surtax on undistributed profits. See I936 Act, § I4 (a) (I).

94. See 1936 Act, $\$ 14$.

95. See I936 Act, \$ 40I, amending I935 Act, \$ 105.

96. See I936 Act, \$ 402, amending I935 Act, § I06.

97. See r936 Act, § 35ז, amended by I937 Act, § I, 50 Stat. 8r3.

98. "The federal income tax should continue to take account of capital gains and losses. - . In recognition of the fact that capital income and ordinary income are different in character . . - the taxation of capital income might well be segregated from that of ordinary income. . . The rates, however, should not be so high as to discourage normal sales of property." Hendricks, Capital Gains and Losses (r935) 49 HaRv. L. Rev. 262, 287.

99. Since the approval of the I924 Act on June 2, I924. 
cases so that, in a field where certainty is important both to taxpayer and administrator, much more will be gained by a continuation of present provisions with possible amendments than by starting anew with a completely revised set of provisions. Finally it may be said most positively that the use of these provisions for the evasion of tax seldom occurs at the present time and that such use, in such rare cases as there may be, is only negligible in its effect on the revenues. ${ }^{100}$

Ioo. The author's views, to similar effect, have been set forth in Hendricks, Developments in the Taxation of Reorganizations (I934) 34 CoL. L. REV. II98, I22I. 